\title{
New Year Address as a Genre of Political Discourse: Political and Linguistic Research (On the Material of Chinese President Hu Jintao and $\mathrm{Xi}$ Jinping)
}

\author{
Alfiya R. Alikberova ${ }^{1}$, Stefana I. Vukadinovich ${ }^{1} \&$ Rasilya R. Nurmieva ${ }^{1}$ \\ ${ }^{1}$ Kazan (Volga Region) Federal University, Kazan, Russia \\ Correspondence: Alfiya R. Alikberova, Kazan (Volga Region) Federal University, 420008, Kazan, Kremlyovskaya \\ Street 18, Russia. E-mail: alfiakasimova@gmail.com
}

Received: June 2, 2015 Accepted: June 15, 2015 Online Published: June 29, 2015

doi:10.5539/jsd.v8n5p80 URL: http://dx.doi.org/10.5539/jsd.v8n5p80

\begin{abstract}
The urgency of the problem under investigation is due to the increased role on the world stage of the People's Republic of China and the Chinese political leaders. The purpose of this article is to disclose by means of a detailed analysis the New Year congratulations not only of the linguistic portrait of Hu Jintao and Xi Jinping, but also the main achievements and new directions in foreign and domestic policy of the country. The leading approaches to research this problem are a descriptive method; analytical method; comparative and comparative-historical methods which allowed to disclose and analyze fully the content of speeches of Presidents of the People's Republic of China. In the given article we consider the journalistic style as one of makrostyles of the Chinese language; official texts of New Year speeches of political leaders of the People's Republic of China in the XXI century are studied and analyzed fully; stylistic, specific and political features in $\mathrm{Hu}$ Jintao and Xi Jinping's speeches are revealed. The materials of the article can be useful for experts, engaged in studying not only Chinese stylistics, but also the Russian-Chinese relations at the present stage, for employees and teachers of humanitarian disciplines of higher education institutions and research centers. It is also recommended for undergraduate students, post-graduate students and students of the higher school with profound research preparation.
\end{abstract}

Keywords: New Year address, political text, language portrait, Chinese political leaders, genre of political communication

\section{Introduction}

Throughout all history political leaders took a special place in life of society. The success or their failure as politicians is always based on such simple things as productivity of their actions, the promises to society, etc. The latter, speech of leaders of the country in particular, plays a special role, as by means of words direct contact with the people, submission of the programs, temporary solution of certain problems, support of people is possible. All political texts are individual, but they have also such common feature as structure and a strict framework (Budaev, 2010). The analysis of stylistics of these texts always took special place in science (Lemeshko, 2001; Zun, 1997). The urgency of this work is that in the stylistic analysis of texts, both the personality of the leader, and his political views and programs are fully revealed.

The speech of the political leader of the country is a type of the text which is exposed to both semantic and structural analysis. A speaker has to follow a number of the rules, but the speech of each person can be analyzed not only from the personal point of view of, but also as the text which belongs to a certain style (Lu, 2011).

Annually political leaders in the People's Republic of China address the people with the New Year speech (Hu Jintao, 2013, Xi Jinping, 2015). As a rule, it is broadcasted on International Radio, the Central Radio and China Central Television. It is a special type of the political text as possesses such features as rituality and institutionality (Varavkina, 2011). Linguists understand the concept "institutionality", as speech of the representative of a certain social institute, and the carrier of a certain status that predetermines observance and fulfillment of the established status and role and situational communicative norms. Rituality in this case means execution of roles of "patriot" and "national defender", and also the attention is paid that this performance has no single character, and repeats with a certain frequency (Chudinov, 2012). 
New Year address has a certain structure, which is always strictly adhered to the speaker (Kondratenko, 2007). The structure of the text of a congratulation includes the following parts: 1) obligatory frame components (address to the addressee, cliché, general phrases); 2) congratulation part (reason of this address, text of the congratulation itself); 3) the stating part (includes the characteristic of a contribution of all people to achievements of the country) (Beeps, 1998; Zhang, 1963).

The New Year address usually is also divided into structural parts according to pragmatical installations: the address to the audience, is usually the beginning of the text, it is highlighted with the help of intonation; the congratulation - an optative component, as a rule, finishes a congratulation (Kitaygorodskaya, 2002).

Thus, the New Year address contains perfomativa of two types - congratulations and wishes which speech form corresponds to a certain ritual framework.

From the point of view of the contents of the New Year address, it has the characteristic of achievement of the state in the expiring year, mentions of the heavy moments with which the country coped by common efforts of the people, plans for the future and the description of a role of New Year holidays in life of society. Despite a standard set of subjects, they are realized always differently, depending on the politician.

The New Year address can be carried to presidential rhetoric as it is said only by the first person of the country.

\section{Methodological Framework}

During research the following problems were solved: studying and the analysis of official texts of political leaders of the People's Republic of China in the XXI century; choice of one of types of the publisictic text; stylistic and language analysis of New Year addresses; analysis of the specific features of speakers and the semantic analysis of the text within foreign and domestic policy of the People's Republic of China.

To achieve the objectives the complex of the various methods complementing each other was used, in particular: descriptive method; analytical method; comparative and comparative-historical methods which allowed to disclose and analyze fully the content of speeches of Chinese Presidents. Official texts of New Year addresses to the people of Chinese Presidents of the XXI century Hu Jintao and Xi Jinping became the main material for research.

\section{Results and Discussions}

\subsection{Results of the Analysis of the Official Text of Hu Jintao.}

First of all, existence of heading of performance in the Chinese texts should be noted. So, even in the New Year address of Hu Jintao (胡锦涛) there is a name, namely "Promoting peace around the world and to the general development" ("携手促进世界和平与共同发展"), the similar phenomenon is peculiar to China. As it was already told above, the address possesses an obligatory frame component, for example: "Dear ladies, gentlemen, comrades, friends) (《女士们, 先生们, 同志们, 朋友们》). It is a standard form in China; it is used not only in political texts, but also on radio, at the airports and at stations. As a rule, the president addresses to the country in general, but Hu Jintao separately allocates also the special regions of China: "I have honor on waves of the International radio of China, the Central radio and Central television of China to transfer New Year congratulations to all Chinese people, the compatriots living in Special administrative districts of Macao and Aomin, to Taiwan compatriots, to the compatriots living abroad, and also to friends from around the world!" (" 我很高兴通过中国国际广播电台、中央人民广播电台和中央电向全国各族人民，向香港特别行政区同胞 和澳门特别行视台政区同胞，向台湾同胞和海外侨胞向世界各国和各地区的朋友们致以新年的祝福》). The fact that the head of state allocates these regions not only shows their special legal freedoms, but also relationship between the center (Beijing) and these areas, that is very important, as well as for residents of Hong Kong, Macau and Taiwan, and for all state in general.

Important part of the text: conclusions and achievements of the leaving year and plans for next year. These are the main semantic parts in which informative and linguistic values are concentrated. Informative function is shown enough clearly and accurately here: the leader describes last year briefly, allocating only bright moments which had special value for the people, and plans for the future are formulated on the basis of the executed actions in the past. Linguistic feature already depends on person (Krichun, 2011).

Analyzing the speech, we can create a language portrait of the personality. For example, Hu Jintao, summing up the results of 2012, speaks: "This year, the Chinese people, united together, safely and surely met difficulties"(« 中国人民同心协力、攻坚克难、中国经济社会发展呈现稳中有进良好态势、各项事业全面推进、人民生 活持续改善》). In this case it shows the attitude towards people, that exactly they should cope with all difficulties and adversities, they are part of the whole mechanism which moves the state forward. 
In his speech Hu Jintao's pays attention to the achieved results: "In leaving 2012, carrying out policy of reforms and openness, China achieved obvious progress while creating modern society" (2012 年, 是中国改革开放和 现代化建设取得显著成绩的年), he also notes that the main objective isn't reached yet: "Leaving 2012 has important and far-reaching value in the course of social development of China" (2012 年，是中国发展进程中 具有重大而深远意义的一年).Considering the economic sphere, Hu Jintao speaks about the stable economic growth, increase of a standard of living of the population, GDP growth. It is possible to note that social issues are touched very superficially, there is no definite and an even approximately formulated problem. It is reported about light future of society in general. Concrete plans and tasks are also not described. This fact shows unwillingness of the politician to go deep into the matter because, firstly, in each state social problems have acuity, secondly, similar questions are generated by the low-quality executive device, so, in case of the People's Republic of China, bad functioning of party, and it in a priori is impossible.

"In 2013 the government of China and its people will highly hold a great banner of socialism with Chinese characteristics” (2013 年, 中国政府和人民将高举中国特色社会主义伟大旗帜) - shows not only communistic propagandas, but also the relation of the head of state, typical for China. As it was told above, Hu Jintao honored inner-party norms very much which were obligatory for execution. Without following these rules, the development of the socialist state was impossible.

In foreign policy the leader calls for the world. Despite any changes on the international scene, the Chinese people will adhere to a peaceful manner of development. China intends to cooperate further with all countries on the basis of five principles of peaceful co-existence, to support solution of international and regional conflicts in a peaceful manner, to render assistance to the balanced, dynamic and stable growth of the world economies, to play a role of responsible power of the world" (《无论国际风云如何变幻, 中国人民走和平发展道路的坚定 决心决不会动摇。中国将一如既往在和平共处五项原则的基础上积极发展同各国的友好合作，积极推 动采用和平方式妥善解决国际和地区热点问题，努力促进世界经济强劲、可持续、平衡增长，发挥 负责任大国作用》). In his own words he says that China doesn't want at all and won't act as an aggressor in the international relations, as honors freedom of people and realizes importance of stable economics.

"All mankind has only one planet. For providing the world and quiet development, unity and forces of all people of various countries and states are necessary"(《人类只有一个地球, 各国共处一个世界。世界和平与发展需 要各国人民同舟共济共同推进》). Supporting peaceful co-existence of various states, he calls not only Chinese, but also all people for understanding and the termination of all conflicts, especially military. The leader finishes the speech, using an obligatory frame component: "In end, from Beijing I wish happiness and health in New year to all of you!" (《最后, 我从北京祝大家在新的一年里幸福安康》). In China special significance is always attached to the capital therefore the broadcasting fact from Beijing is noted.

\subsection{Results of the Analysis of the Official Text of Xi Jinping.}

In the early years of presidency of Xi Jinping (习近平), to draw conclusions regarding his policy is too early, perhaps it is possible to note just a few areas, but the results of the analysis of his speeches are already able to show him as a strong political figure and reveal his intentions. There are a lot of national Chinese expressions in Xi Jinping's speeches, even in performances, devoted to the international issues. Xi Jinping, unlike the previous leaders, tells about his hobbies, stories from his life.

The New Year speech of Xi Jinping in honor of approach of 2015 has a number of distinctive features, at the same time it is traditional. For example, he uses conventional, like Hu Jintao, words of welcome. Framework is maintained strictly by him as the prolog, namely the address to the people and all region of the People's Republic of China he says in a standard form. "At the moment when we see off old year and we meet new, I have honor to congratulate all citizens of China, representatives of different nationalities, compatriots living in special administrative regions Macao and Aomin, on the island of Taiwan and abroad, friends from the different countries and regions of the world happy New Year!" (《在这辞旧迎新的时刻, 我向全国各族人民，向香港特 别行政区同胞和澳门特别行政区同胞, 向台湾同胞和海外侨胞, 向世界各国和各地区的朋友们, 致以新 年的祝福!»).

Xi Jinping immediately after taking office actively engaged in the issues of corruption and intra-party management. He repeatedly declared about the importance of observance of the law at all levels of the power. This anti-corruption company is aimed at two directions: desire of return of mobility of economic life of China that passes in parallel with system of reforms which are directed to strengthening and private sector development of economy which has to take place against decrease of a role of the state; the leader of the country is aimed at strengthening of his role in party which, first of all, is directed on fight against corruption.

Considering such direction in domestic policy, he pertinently brings up this question in the New Year speech. 
"This year our work was directed on strengthening of party discipline, we fought against formalism, bureaucracy, hedonism and excesses, at the moment it is possible to declare that the situation strongly changed to the best. We strengthened measures for fight against corruption, we punished corrupt officials without tolerance that showed our strong determination to fight against the evil and corruption" (《这一年，我们着力正风肃纪，重点反对形 式主义、官僚主义、享乐主义和奢靡之风, 情况有了很大改观。我们加大反腐败斗争力度, 以零容忍的 态度严惩腐败分子, 显示了反腐惩恶的坚定决心»). It is important that Xi Jinping, as active fighter of the party against corruption, in the speech tells also about roles of all participants and the people in this difficult business.

$\mathrm{Xi}$ Jinping is perceived, as the reformer. Even if it is still early to draw conclusions about results of his domestic policy at this stage, his intentions are quite obvious. Active, but not a radical reform of the political, economic and social life of China's happening clearly and slowly. A large part of his New Year speech is devoted to this subject. "This year we have actively advanced the reform, solved a large number of complex issues, put forward a number of important measures aimed at deepening the reforms, most of which are closely linked with the public interests”. (《这一年, 我们锐意推进改革, 啃下了不少硬骨头, 出台了一系列重大改革举措, 许多 改革举措同老百姓的利益密切相关》). It is important that the society is paid the attention to, particularly in the words that most part of the government efforts is aimed at improving the life of people. But his words lack clear definition of the reforms and description of the results; only common phrases, which are aimed at the emotional impact, at the faith in the righteousness of the party's activities. "We have adapted ourselves to the new situation in economic development, actively engaged in the promotion of socio-economic development, the living standard of population has greatly improved”. (《我们适应经济发展新常态, 积极推动经济社会发展, 人民生 活有了新的改善》). Mixing of economic and social spheres plays in this case the agitation and propaganda function of socio-political text. Returning to the intention of Xi Jinping to reduce the role of the state in the economy: these words display a desire of the party to increase a share of small businesses, which will have a beneficial effect not only on the economic level of the country, but will also improve the social sphere of society.

"Our staff at all levels has been working hard for implementation of operational plans. Of course their successful implementation would not have been possible without the support of the people. So, I particularly want to pay tribute to our great nation”. (《为了做好这些工作，我们的各级干部也是蛮拼的。当然，没有人民支持，这 些工作是难以做好的, 我要为我们伟大的人民点赞》).

"This year we have approved at the legislative level such important dates as the Memory Day of the victory in the resistance war of the Chinese people against Japanese invaders, the Memory Day of the Fallen Soldiers, a Day of Mourning for the Nanjing Massacre Victims; and we have held a memorable ceremonies on these dates. Anyone who gave their lives in the name of the state, nation and piece will be remembered and honored for their great sacrifice and contribution, no matter what changes occur in our world”. (《这一年，我们通过立法确定了 中国人民抗日战争胜利纪念日、烈士纪念日、南京大屠杀死难者国家公祭日，举行了隆重活动。对一切 为国家、为民族、为和平付出宝贵生命的人们, 不管时代怎样变化, 我们都要永远铭记他们的牺牲和奉 献》).

The basic functions of journalistic style, particularly agitation-propaganda and emotional expressive, can be traced very clearly in these passages. Such inspiring words produce a very strong influence on the Chinese people having the philosophy notable for their ancestors worship.

The first function is implemented through a high degree of expressiveness and emotion of the text itself. Emotional-expressive function is distinguished by its open evaluation quality. The related topics are always raised for the sake of influencing people. Political speech is always solemn and is a product of the advanced ideology, in this case - of Xi Jinping and the party as a whole. These words cannot but touch every Chinese, since for them it has been a very difficult period in their history. Through the New Year speech the leader of the country affects the people; but it is not only emotional, but also logical and reasoned one.

This theme continues, when $\mathrm{Xi}$ Jinping tells about incidents of the passing year. "This year we have all experienced tremendous sorrow, the flight MN370 of Malaysia Airlines has been earth-out, more than 150 compatriots are still missing to this day, we do not forget them, continue to make efforts in order to find them in all possible ways”. (《这一年, 我们也经历了一些令人悲伤的时刻。马航MH370航班失踪, 150多名同胞下 落不明, 我们没有忘记他们, 我们一定要持续努力、想方设法找到他们》). Xi Jinping does not leave aside the natural disasters that have occurred on the People's Republic of China territory addressing the victims and the relatives of the dead: "This year the country has experienced natural disasters and accidents, a lot of people, much to the misfortune, has passed away. The earthquake in the Ludyan County of the Yunnan province took the lives of more than 600 people; we will remember them, and we wish their relatives and the close ones to cope 
with the anguish of bereavement." (《这一年, 我国发生了一些重大自然灾害和安全事故, 不少同胞不幸离开 了我们, 云南鲁甸地震就造成了 600 多人遇难, 我们怀念他们, 祝愿他们的亲人们都安好》).

Xi Jinping does not sidestep a problem of the fight against corruption, which is a leading direction in the party's internal policy. This active struggle can be explained by the "nepotism" and "localism" presence in the party, the people's treating this phenomenon as normal, open corruption activity.

Xi Jinping, having gone a long way in his political career, is familiar with the particularly acute problems. That is why he holds a very strict policy of combating this "disease" of China. In his New Year speech he declares: "This year we have fulfilled a great job of Party discipline strengthening, we have struggled against formalism, bureaucracy, hedonism and immoderation, and now we can talk about a significant improvement in the situation. We have strengthened measures to combat corruption, with zero tolerance we have punished corrupted officials showing our firm and irrevocable commitment to fight against the evil and corruption”. (《这一年, 我国发生了 一些重大自然灾害和安全事故, 不少同胞不幸离开了我们, 云南鲁甸地震就造成了 600 多人遇难, 我们怀 念他们, 祝愿他们的亲人们都安好》). He informs all Chinese society that, despite the progress made, the work does not end on this stage, it will continue with even greater force.

Xi Jinping stands for a peaceful foreign policy, notes that China has no intention to participate in any international conflicts, on the contrary, it calls on all countries to stop any military actions.

In his New Year address in 2015, he is focusing on China's friendly intentions: "This year we have strengthened contacts with different countries of the world, held an informal meeting of the APEC leaders in Beijing, our country leaders have actively paid visits to other countries, and very often we have also received the leaders of foreign countries in China. All these measures have contributed to a better acquaintance of the world with China's intentions”. (《这一年, 我们加强同世界各国的合作交往, 主办了北京亚太经合组织领导人非正式 会议，我国领导人多次出访，外国领导人也大量来访，这些活动让世界更好认识了中国》).

Finally, the leader of the country shares his hope for a brighter future not only of the Chinese people but also of the whole world: "We are striving to peace; and we hope that the peoples of the whole world will make joint efforts to eradicate hunger and eliminate the threat of war, to the construction of the future where all children could grow in the sunlight of the peaceful times." (《我们呼唤和平, 我真诚希望, 世界各国人民共同努力, 让 所有的人民免于饥寒的煎鰲, 让所有的家庭免于战火的威胁, 让所有的孩子都能在和平的阳光下茁壮成 长》).

\section{Conclusion}

Analyzing the New Year speech as a kind of political discourse it is necessary to note once again that it is characterized by its ritualistic nature. Ritual genres include inaugural address, anniversary speeches, traditional speeches of politicians, which are primarily focused on the ideas of integration and unity of the people expression. Such speeches are always distinguished by their emotional overtones, since their main purpose is the impact on people. Ritualistic nature of the New Year address is explained by the following additional criteria: newsworthiness (namely, a special reason for this speech is a solemn event); temporal localization (television or radio broadcasting is usually conducted annually in a strictly fixed time); and a fixed form.

In terms of the content, the New Year speeches of the Chinese political leaders present the achievements of the People's Republic of China in the past year; they offer plans and set goals for the future. The linguistic analysis of the texts of the leaders' speeches shows an ideological hue, which is typical for China. They support the Chinese people, and through their words lead him to a happy future. During their address to the compatriots they often equate themselves to them, do not uplift themselves and show their importance for the development of the state. Another important feature is the absence of definite facts. If they talk about "international issues", they do not disclose their content; covering topics of Hong Kong, Tibet and Taiwan they only use common phrases regarding hope for good and friendly coexistence of the great Chinese people. This fact can be traced not only in the leaders' New Year speech in 2012 - 2013, but also in 2009 - 2010, when the problems of these regions have been covered very sparingly. Only one sentence has been devoted to the snowfall and the earthquake in the Sichuan Province.

Greater emphasis, as a rule, has been given to the role of the party and to the ideological appeals as well as plans for the coming year. Detailed analysis determines the political intentions of Hu Jintao and Xi Jinping, and reveals them as political leaders.

The purpose of the New Year address as a genre of political discourse is the unity of the people: the political leader not only congratulates the audience with the holiday, but also emphasizes the joint achievements, victories trying to point out the ways to settlement of common problems. By reference to these specific features the New 
Year address has a strictly fixed structure, which is always observed by the leader. But let us not forget that due to the ritual nature of this political text its form plays a major role, which can be traced in the speech made both by Hu Jintao and in the address of Xi Jinping. As a rule, the content is in one way or another known to the listener, but this does not lessen the value of the text, as the solemnity of the situation requires not only to refer to this speech as to a greeting, but also as to a certain result of the work done. Linguistic identity of the leader is manifested here though not so bright, but still the New Year address plays a special role for the people. Due to its ritual nature this rite can be traced not only at various stages, but it is possible also to note the development and the impact degree of the leader, his growth as a language person.

\section{Acknowledgments}

The work is performed according to the Russian Government Program of Competitive Growth of Kazan Federal University.

\section{References}

Budaev, E. B. (2010). Metodologija politicheskoi lingvistiki. Politicheskaja lingvistika. Moskva, 231.

Chudinov, A. P. (2012). Politicheskaja lingvistika. Moskva, 53.

Gudkov, D. B. (1998). Ritualy i pretsedenty v politicheskom diskurse. Politicheskij diskurs v Russia. Moskva, 36.

$\mathrm{Hu}$, J. T. (2013). Pozdravlenie predsedatelja KNR na kitaiskom. Retrieved from http://paper.people.com.cn/rmrb/html/2013-01/01/nw.D110000renmrb_20130101_2-01.htm

Kitaygorodskaya, M. V., \& Rozanova, V. V. (2002). Sovremennaja politicheskaja kommunikatsija. Moskva, 239.

Kondratenko, N. V. (2007). Novogodnee obraschenie kak ritualnuj ganr politicheskogo diskursa: makrostrukturnye komponenty $i$ sredstva ih vyrazhenija. Retrieved from http://www.dialog-21.ru/digests/dialog2007/materials/html/45.htm

Krichun, Yu. A. (2011). Jazykovaja lichnost politicheskogo dejatelja: diskursivnye harakteristiki. Kandidatskaja dissertatsija. Kubanskii gosudarstvennyj universitet. Krasnodar. Russia.

Lemeshko, Yu. G. (2001). Jazyk kitaiskogo obschestvenno teksta. Stilisticheskij i sintaksicheskij analiz. Kandidatskaja dissertatsija. Sankt-Peterburgskii gosudarstvennyj universitet. Sankt-Peterburg. Russia.

Lu, T. (2011). Lingvisticheskii analiz kitaiskih pravitelstvennyh press-konferensii. Politicheskaja lingvistika, $1(35), 260-262$.

Varavkina, V. Yu. (2011). Novogodnee obraschenie glavy gosudarstva: zhanrovaja spetsifika I lingvocognitivnoe modelirovanie obraza adresata. Avtoreferat kandidatskoi dissertatsii. Omskii gosudarstvennyj universitet. Omsk. Russia.

Xi, J. P. (2015). Novogodnee pozdravlenie. Retrieved from http://echo.msk.ru/blog/echomsk/1466598-echo/

Zhang, G. (1963). Stilistika sovremennogo kitaiskogo jazyka. Tianjing, 398.

Zun, T. (1997). Istorija sovremennoi kitaiskoi publitsistiki. Zhejiang, 279.

Ci Zinypin. (2015). Pozdravlenie predsedatelja KNR na kitaiskom. Retrieved from http://news.xinhuanet.com/politics/2014-12/31/c_1113846581.htm

\section{Copyrights}

Copyright for this article is retained by the author(s), with first publication rights granted to the journal.

This is an open-access article distributed under the terms and conditions of the Creative Commons Attribution license (http://creativecommons.org/licenses/by/3.0/). 